\title{
Interactive comment on "Seasonal behaviour of tidal damping and residual water level slope in the Yangtze River estuary: identifying the critical position and river discharge for maximum tidal damping" by Huayang Cai et al.
}

Huayang Cai et al.

liuf53@mail.sysu.edu.cn

Received and published: 20 January 2019

Please find our responses to comments raised by Reviewer \#1 in the attached file.

Please also note the supplement to this comment:

https://www.hydrol-earth-syst-sci-discuss.net/hess-2018-524/hess-2018-524-AC1- 
524, 2018.

HESSD

Interactive

comment

Printer-friendly version

Discussion paper

(c) (i) 